\title{
REFORMING THE AUTOMOBILE TORT SYSTEM
}

\author{
J. H. LAYCRAFT, Q.C.*
}

The author discusses within a broad framework the topic of reforming the automobile tort system. The historic background of automobiles and litigation in the 20th Century, as well as the numerous commissions and inquiries within the last ten years, prompt the author to investigate the present Alberta system for areas in need of reform. The gratuitous passenger, the wrongdoer, the uninsured driver, and the person injured by mischance provide a background against which a detailed discussion of the present Alberta system, and the proposed reforms in Western Canada is undertaken. Mr. Laycraft enumerates six specific criticisms of the present system, examines each in detail as a possible reason to justify reform, and concludes that the case for reform has not been validated. The author then proceeds to enumerate four reasons in support of the present system. Finally, the roles of the gratuitous passenger and compulsory insurance are also examined by discussing their relative positions in the present system and proposing how these positions could be altered through reform to develop a better system.

\section{INTRODUCTION}

The social problems inherent in a just and complete system of reparations for vicitms of automobile accidents have been of increasing concern since World War II. This concern has manifested itself in a large volume of literature on the subject, in legislative experiment and in formal public inquiries into the efficacy of the present social institutions now attempting to solve this complex problem. Prior to the recent inquiry in Alberta by the Legislative Committee on Automobile Insurance, formal Inquiries had been conducted in British Columbia,' Nova Scotia" and Ontario" and to a greater or lesser degree, common law rules governing liability have been modified in Saskatchewan and British Columbia, and in several of the United States.

This article will consider the proposals for change in present systems of compensating for injuries and losses from automobile accidents, with particular emphasis on the reforms proposed or adopted in Western Canada. Consideration will also be given to the related subjects of the gratuitous passenger and compulsory insurance.

It has been said that the history of the law is change, and this is certainly true of the law relating to automobiles. In 1909 a majority of the Divisional Court in Ontario' found it an unreasonable use of the highway to leave parked, an automobile so gaudy with bright red paint and brass fittings that it frightened a horse. As late as 1912: litigants were still able to argue that an automobile is inherently dangerous, and that the owner is absolutely liable without fault for all damage resulting from its existence. After full argument before an Appeal Court, the contention was rejected. The judgment is notable for the prophetic observation quoted from a Georgia court that"

It is not the ferocity of the automobile that is to be feared, but the ferocity

- James H. Laycraft. B.A.. LL.B.i. IAltal of Snucier. Jones. Pcacock. Black, Gain. Stratton and Laycraft. Calgary. Aliberta.

1 Royal Commission on Automobile Insurance. July, 1968.

- Commissioners of Public Utilities Inquiry, 1965.

3 Select Committee on Automobile Insurance. 1963.

Mclntyre v. Coote (1909) O.L.R. 9.

: Campbell v. Pugsiey (1912) 7 D.L.R. 177.

; Campbell v. Pugstey. id.. at 181 referring to Leuris v. Amorous (1912) 3 Ga. App. 50 
of those who drive them. Until human agency interferes they are usually harmless ....

These concepts, so foreign today, demonstrate that our legal system has achieved a high degree of success in assimilating the tremendous changes of the twentieth century. Criticism of the system is, of course, part of the necessary search for improvement and should, therefore, be welcomed by our profession.

Nevertheless, though change in the law is inevitable and desirable, care must be taken to ensure that it is a change which the people of our society want and not merely a change which the sociologist or moralist says they should want. Any abandonment of the fruits of long legal experience must proceed only with the assurance that that which replaces the old system will work the advantage that society desires.

\section{THE PRESENT ALBERTA SYSTEM}

Since the proposals for reform of automobile insurance involve fundamental changes in concept, a review of the principles of the present system seems useful.

The automobile tort system depends upon fault, and is founded upon an adversary method in which the testimony presented is tested by cross-examination. It seeks to determine liability, case by case, on the basis of deviation from an established standard defined in terms of the reasonable man, and seeks to determine the damage actually suffered by each individual upon an analysis of his personal situation and upon consideration of him as an individual. Except in considering damages for loss of expectation of enjoyment of life in fatal accident cases, resort is not had to arbitrary or generalized compensation scales. Finally, except where alcohol is involved, the risks inherent in the operation of an automobile are insurable even though the loss results from the civil or criminal wrong-doing of the insured.

Though the deviation from normal in the doctrine of "negligence" is the foundation of the system, the common law has been modified in several important respects. The most important changes are:

1. The creation of The Motor Vehicles Accident Claims Fund enables a claimant to recover from the fund that which is irrecoverable against an uninsured and impecunious driver, or against the hit-and-run driver, for damages up to $\$ 35,000.00$ and costs for all claims arising out of one accident.'

2. The Motor Vehicle Accident Claims Act provides" for the reimbursement of the expenses of hospital or medical treatment or ambulance service to Alberta residents or to non-residents injured by an Alberta vehicle, regardless of fault, where the applicant has no other prepaid medical scheme or insurance available to him. There is subrogation for these payments upon ultimate recovery from some other person. In the result, a wrong-doer ultimately pays these expenses incurred for another person but not for himself.

3. The rigorous common law rule, still in effect in many of the United States, preventing recovery by a claimant who has himself been

i The Motor Vehicle Accident Claims Act, S.A. 1964, Ch. 56. Sec. 3.

Id., Sec. 13.

i) Id., Sec. 19. 
negligent in any degree, has been abolished and provision has been made for apportionment of liability. " Provision has also been made for contrbiution as between tortfeasors."

4. The common law rule preventing recovery of damages for the death of a human being": has been modified to permit recovery by those dependants who have suffered financial loss from his death ${ }^{13}$ and for loss of expectation of life, pain and suffering before death, and funeral expenses by the estate of the deceased. ${ }^{14}$

5. While Alberta has stopped short of requiring all drivers to be insured, an attempt has been made to induce them to insure the risks of automobile operation. Uninsured drivers applying for a license must make a contribution of $\$ 20.00$ to The Motor Vehicles Accident Claims Fund": in addition to the normal contribution made by all drivers. Moreover, after a motor vehicle accident for which he is responsible, a driver may be required to furnish proof of financial responsibility either by insurance or guarantee bond."

This so-called "Green Certificate" system has increased the percentage of insured vehicles on Alberta roads from about $75 \%$ to about $95 \%$. There are, however, more than 18,000 uninsured vehicles still operating in Alberta. ${ }^{1 i}$

Clamour for reform of traditional automobile tort systems has usually centered around the victim of the automobile accident who fails to receive assistance from any source other than medical payment schemes or welfare agencies. In Alberta, under the present system, the following classes of uncompensated victims may be identified:

1. The wrongdoer who caused the accident receives either no compensation or has it diminished if responsibility is apportioned, but may receive reimbursement for medical, hospital or ambulance service. The uncompensated wrongdoer is the outstanding feature of the "tort" or "fault" concept and the fundamental change to be achieved by the "no-fault" system is to ensure recovery by all, including the wrong-doer, of some portion of the damages suffered.

2. The gratuitous passenger, injured by the negligent, but not grossly negligent, act of his own driver, either fails to recover anything" or has his recovery diminished by apportionment.":! It would appear that this class of persons is substantial in size but no accurate enumeration is possible since in clear-cut cases, no action or other proceeding provides a means of compiling statistics. This problem will be considered later in this article.

3. Those persons injured by the fault of an impecunious driver, who is uninsured or inadequately insured, will not recover compensation above the limit of the insurance or the limit of The Motor Vehicle Accident Claims Fund. Any practising lawyer can give examples of such cases. A notable one in Alberta is that of the young professional

10 The Contributory Negligence Act. R.S.A. 1955, Ch. 56, as amended.

11 The Tort-Feasors Act. R.S.A. 1955. Ch. 336.

1: Baker v. Boulton (1808) 170 E.R. 1033.

i: The Fatal Accidents Act. R.S.A. 1955. Ch. 111. as amended.

1. The Trustee Act. R.S.A. 1955. Ch. 346. ss. 32-34, repealed and replaced by The Administration of Estates Act. S.A. 1969. Ch. 2. ss. 54-56.

1: The Motor Vehicle Accident Claims Act, S.A. 1964, Ch. 56, Sec. 5.

1i: The Highway Traffic Act. S.A. 1967, Ch. 30, Secs. 246-250.

17 Report of Special Legislative Committee. 1969, at 8.

iv The Highway Traffic Act, S.A. 1967, Ch. 30. Sec. 211.

1!: The Contributory Negligence Act. R.S.A. 1955, Ch. 56. Sec. 4. 
engineer with a young family, who was blinded in a collision with an uninsured wrongdoer. His recovery of $\$ 10,000.00$ under the then existing provisions of the Fund was probably $1 / 15$ th of his actual damage.

4. Those persons injured in an accident caused by sheer mischance, and without the fault of any person, receive only reimbursement for medical, hospital or ambulance service. The driver who collides with a wild animal which jumps suddenly onto the road, is a clear example.

A recent study in Ontario" found that the tort system, by itself, fell far short of providing full economic reimbursement for all the injury victims. Some 57 percent recovered nothing at all from an adversary in the tort system, though various medical schemes ameliorated their lot considerably. A large proportion of these persons were, of course, uncompensated wrongdoers. Another large class were the gratuitous passengers who, at the time in Ontario, were precluded from recovering anything from their own driver even if he was grossly negligent. Thus the proportion of persons uncompensated for their injuries was probably larger in Ontario than in Alberta. It can hardly be doubted, however, that large numbers of accident victims in Alberta are either not compensated at all or are compensated inadequately. If, as Professor Linden observes, "the sole goal of tort law is to compensate everyone injured (a questionable assumption) it has failed ....".

Of these classes of uncompensated victims, the gratuitous passenger and the person injured by mischance can be compensated by relatively minor changes to existing systems. Compulsory insurance can improve the lot of those injured by the negligent, impecunious driver. The real issue of any present inquiry into the automobile tort system is to consider whether that system should also compensate the negligent driver despite the fact that his loss flows from his own act.

\section{REFORMS PROPOSED OR ADOPTED IN WESTERN CANADA}

\section{A. The Wootton Report:}

In 1966 a Royal Commission under the chairmanship of The Honourable Mr. Justice Wootton was established in British Columbia to enquire into various aspects of automobile insurance and compensation to victims of automobile accidents. The Commission reported in July, 1968 and recommended far-reaching changes in the British Columbia system. The most fundamental of these recommendations envisaged the abolishment of the traditional automobile tort system by taking away the cause of action in tort. This would be replaced by a system of compulsory insurance providing for a scale of arbitrary sums payable to all injured persons regardless of fault.

The compulsory insurance would continue to be issued by the private insurance industry, the rates being subject to supervision by governmental controls.

Regardless of differences in the individual circumstances of victims of automobile mishaps, the payments would vary little between them. Maximum death benefit of $\$ 20,000.00$ is reduced on a graduated scale

"I Linden. Osgoode Hall Study on Compensation for Victims of Automobile Accidents,

$\approx$ Linden, Tort Faults and Benefits, The B.C. Agent. December, 1968. 
to $\$ 1,000.00$ for infants under five years of age. Disability benefits would be $\$ 50.00$ per week to all persons over 18 regardless of occupation, and would be reduced under that age on a fixed scale. There would be no coverage for pain and suffering, disfigurement, loss of income in excess of $\$ 50.00$ per week or any sum in excess of $\$ 20,000.00$ for death. No coverage whatever was recommended for property damage, though collision insurance would be available on a voluntary basis.

It is interesting to note that the Commission recommended a mandatory $\$ 100.00$ deductible provision on property damage because it felt this provision would

give owners an incentive to practice defensive driving in the newly created driving environment. Lower deductibles, while more costly, may increase irresponsible driving due to the fact that purchasers of such, secure in the thought that their own vehicle is protected, may jeopardize the safety of others.

If we accept this reasoning, of necessity we are driven to speculate whether the removal of all responsibility for injury or damage to others, as recommended by the Commission, might not precipitate a new era in irresponsible driving.

With respect, the recommendations of the Commission on property damage are not well reasoned and would not accord with the sense of justice of the average man. If a citizen has his parked car struck or hit in traffic by a vehicle going through a red light, he will be out of pocket by the amount of $\$ 100.00$ deductible and would find that his cause of action to recover it has been abolished. Perhaps he would find only minimal comfort in being told that he is being trained in "defensive driving" by the provision that his $\$ 100.00$ deductible cannot be recovered from the wrongdoer. Moreover, modern vehicles can cause quite spectacular property damage in collision with objects other than another automobile. The owners of this property would not even be afforded the comfort of new-found skills in "defensive driving".

A majority of the Alberta Legislative Committee also recommended this $\$ 100.00$ deductible provision for third party liability, basing the recommendation solely on the expense of insuring this portion of the loss. The result in many instances, however, would be that the innocent owner will simply pay this portion himself, since the legal system does not function well in the recovery of $\$ 100.00$ claims. There will be a tendency, in any event, to inflate petty claims, so that the saving is apt to be illusory.

It is in the field of damages for personal injury or death, however, that the greatest changes would occur from the Commission recommendations. Illustrations of actual cases decided under the present system and computed under the Commission's proposed scales will demonstrate how far reaching were its proposals.":

1. An 18 year old plaintiff was rendered unconscious and suffered multiple lacerations. He was off work for one year, had permanent scars and impairment of his sense of smell and of his sex function. $\mathrm{He}$ was awarded $\$ 25,000.00$. Under the recommendations of the Wootton Commission, only the absence from work would be compensable, for a total of $\$ 2,600.00$.::

2. The plaintiff suffered a whip-lash injury which aggravated pre- 
existing degenerative changes in the neck. He spent 20 days in hospital and was absent from work for a further month. For a considerable period thereafter he was forced to wear a canvas corset. Damages were assessed at $\$ 4,500.00 .^{2+}$

Again, only the actual lost time would be compensable. Approximately three months would give compensation of $\$ 600.00$ compared to $\$ 4,500.00$ assessed.

3. A 20 year old stenographer sustained a severe complicated fracture of the pelvis, femur, ilium and pubic bone. After an operation to insert plates and screws, the fractures were restored to a reasonable but still imperfect condition. Subsequent infection necessitated further operations. The plaintiff would always have a pronounced limp. She had lost 9 months' work. Damages were assessed at $\$ 35,000.00$

The compensation under the Commission's scale would be approximately $\$ 2,000.00$, though here actual loss of earnings alone was $\$ 5,000.00$.

In all cases of serious injury, the damages recovered under the Commission's recommended scale would be markedly less than present awards by the court. Where permanent partial disability or disfigurement is involved and in cases of extremely painful injuries the difference will be most marked, because the no-fault system does not compensate for this class of injury.

In fatal accident cases, however, the payment under the Commissions' scale would occasionally be higher than court awards. Also, since the no-fault system gives no consideration to individual variations in circumstances and has no machinery to evaluate them, individuals in greatly different conditions receive the same awards.

4. An 88 year old pensioner died shortly after being injured in traffic. The financial benefit lost by the plaintiff was $\$ 45.00$ per month for the life expectancy of 3.5 years. Damages, including funeral expenses, were fixed at $\$ 2,272.00$.: Under the Wootton Commission scale, damages would have been $\$ 20,000.00$.

5. A 33 year old mine manager, killed in a motor vehicle collision, left a 35 year old widow and an 8 year old daughter. His average earnings had been $\$ 6,500.00$ per annum. Damages of $\$ 70,000.00$ were awarded, from which was deducted the financial benefits from death."i Under the Commission's scale, this claimant would receive precisely the same as the claimant in Example No. 4-\$20,000.00-though the circumstances of the two cases were not remotely comparable.

These examples were chosen to illustrate various awards for serious injury as compared to less serious injury and for death under various circumstances. They were not however, chosen to make the point of marked disparity. Virtually every one of the hundreds of actual cases reported in this useful Canadian manual on damages ${ }^{2}$ would show similar disparity. The significant result of this review is that when the individual's actual circumstances in life are ignored, when no account is

$\because 4$ Balatoni v. Crowley, Goldsmith, supra, n. 22 at 159.

:- Magumi v. Mendum. Id. at 199.

$\because i$ Williams v. Grice, Id. at 391 .

$\because$ Montreal Trust Co. v. A.G. of Nova Scotia (1959) 21 D.L.R. (2d) 287.

¿ Goldsmith, supra. n. 22. 
taken of pain and suffering or disfigurement or of such factors as the diminished prospect of happy marriage, justice simply is not done.

It is submitted, with all respect to the learning and industry of the Commission, that citizens cannot be treated as mere cyphers who can be compensated simply by reference to a printed table. People are individuals. There is a difference between a young father and an 88 year old pensioner. The ruined life of a young man or woman must be taken into account. To ignore these truths in the name of expediency is to abandon the fundamental role of every legal system-that it achieve justice. The legal system must recognize that each of our citizens is unique and entitled to have his individuality respected.

A fixed compensation scale has, of course, been used in Workmen's Compensation programs for many years, and it is argued that the same concept can be used to fix compensation for automobile victims. It may first be observed that the scale of payments under Workmen's Compensation system does vary in accordance with the workman's income. Moreover, in many cases, compensation to an injured workman is not a payment in lieu of a cause of action against his employer. The workman would recover nothing from his employer in such cases.

Mr. W. David Griffiths, Q.C., has made this point in the following terms: ${ }^{29}$

There is a substantial difference between the common law governing industrial accidents which forced a change and the present day common law system for automobile accidents. Under the old master and servant law, the ability of the injured workman to recover was greatly circumscribed by the common law defences of assumption of risk, contributory negligence and common employment. The old law was regarded as a conspiracy to throw the losses of industrial accidents onto the employees at a time when they were conspicuously less well off than their employers. There is no comparable harshness in the tort law of automobile accident cases and in fact our courts and the laws sympathize with and tend to lean towards the injured plaintiff.

- Undoubtedly the arbitrary compensation scale achieves some simplicity. It would reduce the work-load on courts and it may achieve distribution of the pool of funds available with less overhead expense, although even this point is doubtful. Any advantages of the system are achieved, however, at great expense. Some claimants will be overcompensated and some grossly under-compensated because the individual circumstances are ignored.

\section{B. The British Columbia Legislation ${ }^{: 00}$}

The British Columbia Legislature did not take the full dose of medicine prescribed by The Wootton Royal Commission, and left traditional tort principles in operation for cases of very serious injury. Nevertheless, far reaching changes were made by a series of legislative changes to The Motor Vehicle Act:"' and The Insurance Act:": at the 1969 session of the Legislature, although most of the changes are not yet proclaimed in force.

Public liability insurance will be compulsory for all drivers with minimum limits of $\$ 50,000.00$ for coverage. Payment of benefits will be

2!! Griffiths, Don't Abolish Tort Law in Auto Accident Compensation, (1969) 12 Can. Bar Jo. 187.

(11) The writer is indebted to Mr. G. R. Schmitt of Vancouver, who kindly provided his notes of a lecture given to the Faculty of Law, University of British Columbia. analyzing the new legislation.

:it The Motor-Vehicle Act, R.S.B.C. 1960, Chap. 253, amended by S.B.C. 1969, Ch. 20.

3:- The Insurance Act, R.S.B.C. 1960, Ch. 197, amended by S.B.C. 1969, Ch. 11 . 
made to the limits of the policy regardless of fault, the one exception to this provision being that a victim of the mishap who is convicted for impaired or drunken driving may not recover.

The cause of action for property damage caused by an automobile is abolished in these words: ${ }^{:: 3}$

(1) Subject to Subsection (2) no action shall be brought against any person for recovery of damages to property occasioned in an accident involving a motor-vehicle exceeding two hundred and fifty dollars and costs.

(2) Subsection (1) does not apply to a person ordinarily resident outside the Province.

With respect to claims for personal injury (as distinct from property damage) the right of action against a wrongdoer is not taken away. The fact that the accident victim received benefits under the no-fault provision of a policy will, however, affect his rights in an action against the wrongdoer. The judgement against the wrongdoer will be reduced by the amount of no-fault benefits the plaintiff has received, provided the wrongdoer himself had a policy of "no-fault" insurance.

The special statutory provisions relating to gratuitous passengers were repealed.

The schedule of accident benefits under the "no-fault" policy occupies $4 \frac{1}{2}$ pages of fine type. These benefits include medical and hospital services in excess of those recoverable under government schemes and death benefits ranging from $\$ 500.00$ for infants to $\$ 5,000.00$ for the head of a household, increasing by $\$ 1,000.00$ for each survivor after the first survivor. In addition, there are weekly payments for 104 weeks of $\$ 50.00$ for the first survivor and $\$ 10.00$ per week for other survivors.

If, for example, $\mathrm{X}$, a 35 year old man, is killed by the negligence of $Y$, leaving a dependent wife and three children, the no-fault policy would pay:

$\$ 5,000.00$ for the wife

$3,000.00$ for the children

$5,200.00$ in weekly payments to the wife

$3,120.00$ in weekly payments to the children

$\$ 16,320.00$

This is paid by X's insurance policy. If X's widow then sues $Y$ and the damages are assessed at $\$ 40,000.00$, her judgment is reduced by $\$ 16,320.00$ recovered under the no-fault provision, leaving here a judgment of $\$ 23,680.00$. The judgment is paid by Y's insurer, and since there is no subrogation under the no-fault payment, $Y$ 's insurer has the benefit of the payment by X's insurer.

This curious result will undoubtedly lead to remarkable manoeuvering by insurers. There appears to be no provision requiring survivors to claim under the no-fault provision. Thus, one can expect that X's ininsurer will hasten to induce the widow not to claim under X's policy until remedies have been exhausted against $Y$. An extra payment to $X$ 's widow to sue $Y$ first does not seem to be forbidden.

Disability benefits are payable at between $\$ 40.00$ and $\$ 50.00$ per week for 104 weeks to wage earners who are totally disabled during

33 Id., 5.79. 
that time. If at the end of 104 weeks, the injured wage earner continues to be totally disabled, these benefits are continued to age 65 and are then reduced by the amount the individual receives from old age pensions or Canada Pension Plan. A totally disabled housewife will receive $\$ 50.00$ per week for up to 26 weeks. There would be no payment for pain and suffering or for partial disability.

These benefits are minimums, and any individual could presumably purchase insurance with higher limits. Thus a policy of accident insurance limited solely to automobile accidents and with beneficiaries other than the purchaser, has been engrafted onto present insurance protection and all drivers have been compelled to purchase it.

It will be seen that the British Columbia legislation produces a half-way house between the present tort system of compensation for automobile cases, and no-fault systems such as that proposed by the Wootton Commission. For property damage it adopts no-fault concepts, leaving the cause of action only for the amount of the deductible. For personal injury and death it leaves an action in tort available, but adds a basic accident insurance made compulsory and based upon an arbitrary scale of damage. An attempt is made to provide some compensation for every class of injured persons, with the sole exception of impaired or drunken drivers, but including every other wrongdoer.

\section{The Saskatchewan System}

The Automobile Accident Insurance Act in Saskatchewan ${ }^{34}$ came into effect on April 1, 1946. It provided a government administered basic no-fault insurance while retaining the tort system for compensation above the limits of the basic protection. Coverage is compulsory and a condition of vehicle registration.

Death benefits to a primary dependant are $\$ 5,000.00$, and to a secondary dependant are $\$ 1,000.00$ up to a $\$ 10,000.00$ limit. Death benefits for children vary from $\$ 100.00$ to $\$ 1,000.00$, depending on age and for an unmarried adult are fixed at $\$ 1,000.00$. Disability benefits for permanent disabilities are in lump sum payments according to a fixed schedule with a maximum of $\$ 4,000.00$. Weekly indemnities for temporary disabilities vary in amounts from $\$ 12.50$ to $\$ 25.00$, and are payable for up to. 104 weeks. These payments are in addition to permanent disability benefits. A discretion is given to make a supplementary payment of $\$ 2,000.00$ for out-of-pocket expenses.

The claimant may still advance a cause of action for negligence, in which event the amount received is diminished by the above payments. Voluntary extended coverage may be obtained from either the Government office or from private insurers.

As in the British Columbia system, there is no recovery of the "nofault" benefits by a person who was injured while an impaired or intoxicated driver.

The essential feature of the Saskatchewan insurance scheme is that it is government insurance, since the no fault provisions would provide minimal assistance in all but the most serious cases. It operates as conventional insurance of rather limited coverage, apart from those limited no-fault benefits.

34 The Automobile Insurance Act, S.S. 1946, Ch. 11 . 
D. The Report of the Alberta Committee

The Legislative Committee on Automobile Insurance established by The Legislative Assembly of Alberta in 1969, issued its report in March, 1970. The recommendations are similar to those contained in the British Columbia legislation.

Automobile insurance is to be compulsory and is to be left with the insurance industry, subject to control of the rate structure, to a limit of $\$ 35,000.00$. Accident benefits, regardless of fault, would be paid for death on a sliding scale of from $\$ 500.00$ to $\$ 5,000.00$ with weekly benefits similar to those in British Columbia, and with the same disability benefits.

Uniform premium structures are recommended regardless of age or geographical location.

While the Committee adopts the "no-fault" concept, it is not expressly stated in its report whether the "no-fault" payments would be deducted from ultimate recovery under the tort system. Presumably since there is no recommendation to abolish the cause of action in tort and damages would ultimately be assessed under the traditional rules, these benefits would be deducted.

The Committee recommends an end to special rules for gratuitous passengers.

\section{SHOULD THE AUTOMOBILE TORT SYSTEM BE ABOLISHED}

A. Criticisms of the Present System

A proposal to change a long established code of legal rules can be considered only if that system has serious defects apparent in its operation. Critics of the present automobile tort system have been increasingly on the offensive, and though many of the criticisms have reference only to conditions in some United States jurisdictions, the whole judicial procedure involved in the automobile tort system has come under attack. Keeton and O'Connell gave the following capsule criticism of the present system: ::

It provides too little too late, unfairly allocated, at wasteful cost, and through means that promote dishonesty and disrespect for the law.

This is damning criticism, unless, indeed, a survey of the actual workings of the system establish that it is nothing more than a well expressed exercise in invective. The criticisms of the present system will be listed and then considered in the light of Alberta experience.

The defects are said to be six in number:

1. There is a great delay involved in determining fault and assessing damage.

2. The present system is unreliable in its fact determinations because of the complexity of modern traffic and is uneven in application. Some claimants get too little; some (particularly those with small claims) get too much.

3. The system is unduly expensive; its fact considerations involve a cumbersome procedure with elaborate safeguards, and as automobile traffic becomes denser the court system will finally become overwhelmed by sheer volume.

3.5 Keeton \& O'Connell, Basic Protection for the Traffic Victim, (1965) at 3. 
4. The system "is marred by temptations to dishonesty that lure into their snares a stunning percentage of drivers and victims".36

5. Death benefits are too low.

6. The system leaves large numbers of traffic victims uncompensated.

\section{Delay}

For centuries the literature of the English language has contained complaints about the law's delays. ${ }^{37}$ Discussions of the automobile tort systems continue this tradition and in many instances criticism involving the administration of the system and of the judicial procedures involved have validity. Nevertheless much has already been done in Alberta to speed the judicial procedures, and care must be taken to ensure that this particular criticism doesn't achieve validity merely by its repetition.

It is first necessary to fix some standard by which we can judge when delay has in fact occurred. The mere fact that a claim has not been determined for a considerable period does not mean it has been unduly delayed. A proper fixation of damages can usually not be done until there has been a sufficient lapse of time to ensure that all the medical evidence is in-that all conditions attributable to the accident have been identified and assessed. Plaintiff's lawyers in Alberta know that one of the early problems with virtually every client is to induce him to endure this period. Most will wish to settle the claim early at a stage when proper assessment of their ultimate disability is impossible and their best interests demand delay. Many such clients will describe this experience to their friends in terms that "it takes a long time", when in fact the elapsed time is a function of their disability rather than cumbersome legal procedures.

Moreover, only a very small percentage of claims ever reach the trial stage. Minor claims are very frequently settled by negotiation between the claimant and an insurance adjuster; slightly more serious claims are settled as a normal procedure between an insurance adjuster and the claimant's lawyer. Where personal injury is involved, the more usual course is settlement by opposing lawyers.

Where facts are seriously in dispute, or where the medical evidence probably won't be in before the expiration of the limitation period ${ }^{3 x}$ an action is commenced by issuance of a Statement of Claim, and an Examination for Discovery is held. The Statement of Claim is itself a simple document, and if disputed facts must be determined, it is difficult to visualize a more streamlined procedure than an Examination for Discovery, attended by the parties, their legal advisors and a Court Reporter, without the intervention of a judicial officer. When agreement fails, a very small percentage of cases go to trial, and then almost always before a judge alone. Civil jury trials are so rare in Alberta that years often elapse between them.

Criticisms of the legal system written in the United States and speaking of years of delay in court lists, and of days spent empanelling a jury for a complex trial lasting days or even weeks simply have no validity in Alberta. If all the preliminary procedures have failed to

3* The extension of the limitation period to two years by the Limitation of Actions Act. S.A. 1966, Ch. 49, enabled a great many more actions to be settled without action having been commenced. 
produce a settlement and a case is ready for trial, only weeks rather than years should be involved in getting it before the court.

The present legal system seems to be the victim of an inconsistent criticism in the area of delay. On the one hand there is criticism that with small claims, insurers are too ready to settle.:"' On the other, much is made of cumbersome legal procedures. Surely no more fair or inexpensive administrative system could be devised in any scheme, government or private, than a negotiation between the claimant or his representative and insurer's representative. It is doubtful that any public board, even applying a fixed scale, would administer the average claim much more cheaply.

Both the legal profession and the insurance industry must be alert to maintain and extend reforms in the automobile reparations system. Legal procedures have recently been extensively reviewed." For its part the insurance industry has recently commenced the use in Canada of an "advance payments" scheme whereby interim payments are made (to claimants) without prejudice to the rights of either the insurer or the claimant on final settlement. The American Bar Association report describes the system in these terms: "1

Many insurance companies are now using the "advance payment" plan of settling cases. Usually the method is reserved for cases in which liability is clear or which are clearly destined to be settled. But a few insurers are finding it useful not to be too strict in drawing the lines. Within a short time of the accident, the adjuster offers, without demanding a release, payment on account of medical and hospital expense, nursing care or for other pressing needs, including, in appropriate cases, income maintenance. The only strings attached are that the payment does not constitute an admission of liability, does not stop the running of the statute of limitations and is to be credited upon any ultimate settlement or judgment.

The technique is too new to have its results show up in the empirical studies, and we know of no authoritative survey that would indicate what impact it will have on court delay or on settlement delay. Judging from the frequency with which it is being discussed in gatherings of claims men and the general tone of the discussions, it is now widely used and its use is continuing to expand.

The well known settlement "on the court house steps" usually indicates unnecessary delay and produces criticism both of the insurance industry and the legal profession. The insurance industry should reexamine its procedures to establish an advance payments system for use in as many claims as possible. It may be that the worry of claims managers of prejudice by advance payment, would be alleviated by a statutory provision that it would be deemed not to be an admission of liability or of the quantum of damage.

Where avoidable delay occurs in fixing or paying reparations to an automobile victim, it is a serious defect. It is usually, however, a procedural defect either in the legal system or in the insurance industry. Such defects can be eliminated; they do not mean that the whole system must be abandoned.

\section{Complexity and Reliability}

The Wootton Commission and other writers on the subject have reached the rather remarkable conclusion that it is not possible to deter-

39 Wootton Report at 506, and quotation from Keeton \& O'Connell, supra $\mathrm{n}$. 35 there included.

40 The new Rules of Court in Alberta are an example. This new Statement of Court Procedures resulted from co-operation of the legal profession and The Department of the Attorney General, and came into force in January, 1969.

11 Report of the American Bar Association, Special Commitiee on Automobile Accident Reparations. See also Wootton Report at 5i7-522. 
mine who was at fault in most automobile accidents." This is in fact a basic premise of the no-fault system, which has no validity at all in Alberta. Facts are determined by those trained to do so and the law is applied, both with accuracy and considerable despatch, in the vast majority of cases.

This view that automobiles produce a fact situation too complex to be unravelled, seems to have arisen from a statement by Professor Leon Green, ${ }^{43}$ widely quoted and apparently adopted as fact by the Wootton Commission. Professor Green described what an automobile driver must do: ${ }^{* 4}$

The operator must observe the operation of other vehicles, front and rear and to the sides-those he is meeting, those that pass, and those that may cross his path. He must observe road signs, stop signs, cautions, traffic lines, light signals and those of traffic officers. He must observe his speed and that of others. He must watch for signals of other motorists and give proper signals himself. He must know the operating mechanisms of his machine; check their operations as he travels, and maintain his rapidly moving and complex machine under control at all times. These and other duties may be required of him every moment of his travel, made specific for the particular situation, all over-topped by the common law duty to use reasonable care under all the circumstances.

Multiply the same duties and hazards by any number of other operators in the immediate vicinity; add the duties and hazards of highway maintenance, passengers, pedestrians, and adjacent landowners, the conduct of any one or more of whom may impose upon all operators in close proximity duties and hazards requiring instant and perhaps unerring judgment and action. Add further the hazards of climatic conditions; the imperfections of the human being in sight, judgment, muscular reaction, health, strength, and experience. Bring any combination of these duties and hazards into focus on a collision at high spced at a particular point of time and place. Who can name all the factors involved in causing the collision? Who can know or discover or describe the conduct of the parties involved? Who in retrospect from the tangled fragments of evidence given by the participants or bystanders and those who arrived on the scene at a later time; from marks and measurements, calculations of time and speed, is expert enough to reconstruct the fleeting scene with any assurance of its accuracy. If the picture by some miracle could be truly presented, who could pass a rational judgment in the allocation of responsibility as between the parties on any basis of fault?

This statement, it is submitted, bears no resemblance to reality; the motorist does indeed have those duties, but not all at once. As The American Bar Report observed, ". . . it is a fanciful description. It is literary rather than scientific". The members of society are attuned to the age in which they live, and when a witness speaks of speed, or traffic conditions, or any of the other causes of auto accidents, he speaks of a matter within his own experience and that of most other members of his generation. The determinations of fact are not that difficult, and in the large majority of cases do not require the intervention of a judge at all.

Determination of the quantum of damage raises greater problems, but that difficulty is not so extreme that society should be driven to give up the attempt altogether as do the no-fault systems. The body of precedent from a functioning court system enables some very good yardsticks to be developed, and it enables the sums awarded to vary from place to place and time to time to coincide with changing conditions. Inflation, for example, is much more quickly recognized in a system of court awards than under an arbitrary scale.

The strength of a system of judicial assessment of damages is that

$4:$ Wootton Report at 509-511. See also. Keeton \& O'Connell, supra, n. 35 at 16-17 and

The American Bar Association Report, supra, $n$. 41 at 9-16 and 68-69.

43 Green. Traffic Victims: Tort Law and Insurance, 44 Id., at 64.

14 Id., at 64. 
the unique factors of each individual case are separately considered. From such consideration, equity in the award is much more apt to occur than from a system in which every broken arm is treated like every other broken arm and every death as entailing the same financial consequences as every other death.

The "uneven award", far from being the attribute of the present system, will be the hall-mark of the no-fault systems. It will inevitably follow from making precisely equal awards to each member of a class of claimants without regard to the individual variations in circumstances. It may well be true that no system of assessment devised by humans will be perfect, but it is submitted that that administered by a trained legal profession, and a trained Judiciary with the safeguard of appeal, will come closer to perfection than the no-fault system which abandons as hopeless the attempt to make an individual assessment.

\section{Expense of the Present System}

The Wootton Commission concluded that British Columbia motorists are paying roughly $\$ 1.60$ in insurance premiums for each $\$ 1.00$ paid to

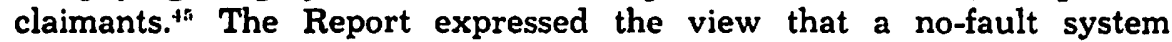
would pay a much higher proportion of the premium income to claimants, though by the nature of the case precise statistics were impossible to obtain. A similar review of Alberta statistics is beyond the scope of this article.

The Wootton Commission viewed this premium-payment ratio as unacceptable. It proposed that a public body be authorized to review insurance premium rates, but this was the only change it recommended which was designed to improve the ratio on the basis of present coverage. In every other respect the proposals of the Commission were designed to scrap present systems. Wrongdoers would be compensated equally with innocents, and administration costs would presumably be reduced by removing from the system any requirement to determine fault or assess damage.

A comparison of the costs of a no-fault system and those of present systems would be virtually impossible. Administration expenses of issuing policies would be about the same. Administration of claims would differ very little in simple cases. In serious cases there would not be the cost of determining fault or assessing damages; on the other hand more people are to be paid.

The Saskatchewan Insurance Office fixed its costs at 18.7 $\notin$ per dollar of claims. In considering this figure we must bear in mind, as the Wootton Commissioners did not, that private insurers covering above the statutory minimums, tend to handle the more serious Saskatchewan claims and that their costs must be added.

After an extensive study, the Wootton Commissioners concluded that charges of the legal profession were $15.9 \% ;$ of the awards; where actions were settled before trial the charges were $11.6 ; ;$ of the awards. No comparable figures are available for Alberta though experience would indicate that Alberta charges would be in the same general range.

Whatever would be the costs to society of the two systems the real question to be answered is whether doing equity between claimants by

1.7 Wootton Report at $\mathbf{4 0 5}$. 
attempting to differentiate between their differing circumstances is worth the costs.

It is submitted that if a no-fault system, which abolishes the tort system completely, is ever removed from the realm of theory and tested in actual operation, it will shock the sense of justice of all who observe it. It will be difficult to convince the family of the 33 year old mine manager in Example No. 5" that they should receive precisely the same compensation as the widow of the 88 year old pensioner in Example No. 4.": The no-fault system must ignore the pain and suffering or the diminished prospects for a happy life of a stenographer in Example No. 34 because it has no means to assess them, and would incur the same problems as the present tort system if it tried to do so.

Justice requires that we be considered as individuals. To put it mildly, it is not a legitimate reason to abandon the attempt to achieve that perfection because the process is expensive.

\section{Dishonesty in the Tort System}

The shocking conclusion of some writers that the judicial system has failed to detect "a stunning percentage" of dishonest drivers and victims has not been supported by any research. Moreover, it is not supported by the experience of the Alberta Bar.

The adversary system has been designed to test evidence by crossexamination, but the principal reason for the effort is not the perjured witness. Rather it is to arrive at the truth from an amalgam of the observations of a number of witnesses, each of whom is honest but each of whom is subject to the human foibles of exaggeration or poor observation. The net result is not perfect, but considered as a human institution, administered by humans, the judicial adversary system has achieved remarkably good results. Conscious dishonesty is rare, and success in conscious dishonesty is even rarer.

In the specific field of automobile investigation, it must also be remembered that in the difficult cases, investigation by experienced, professional adjusters and police commences immediately. It takes a talent for dishonesty, for the victim, injured or at least shocked by the accident, to choose immediately the area in which to colour the truth. In most cases, physical evidence, independent witnesses, and the statements of participants also assist the exposure of inconsistency. Finally, the perjured claimant must run the gauntlet of a trained legal profession and Judiciary and the sanctions of the criminal law.

There is no evidence that dishonesty has so overwhelmed the judicial process that this process must be scrapped. It is submitted that once again facility of literary expression has replaced fact, and that no "stunning percentage" of victims has been "lured into the snare" of dishonesty.

\section{Low Death Benefits}

At common law the rule was stated that "in a civil court the death of a human being cannot be complained of as an injury." In Alberta this has long been modified to permit recovery by dependants of their

\footnotetext{
ti Montreal Trust Co. v. A.G. of Nova Scotia, supra. n. 27.

4: Williams v. Grice, supra, n. 26.

1. Magumi v. Mendum, supra, n. 25.

ii: Baker v. Boulton (1808) 170 E.R. 1033.
} 
actual loss arising from the death." To this extent the problem has been solved. The one remaining area of debate in this field is whether the estate of a deceased person should be permitted to recover for the pain and suffering of the deceased before his death and also damages for the fact that his expectation of a happy life has been taken from him by a wrongdoer. This is at present allowed in Alberta," though the amounts awarded for loss of expectation of life vary from only a few hundred dollars to about $\$ 7,000.00$.

At a recent Law Society convention a debate was held, at which the views expressed ranged from a desire to see abolition of the claims under The Trustee Act (as proposed by the Canadian Conference of Commissioners on Uniformity of Legislation) to advocacy of statutory extension of The Trustee Act provisions so that there would be no difference in any tort rules caused by the circumstance that either the plaintiff or defendant had died before trial. The reader is directed to two papers putting these opposing views.":

It is the writer's personal opinion that The Trustee Act claims should be retained and extended, and that the awards for loss of expectation of life should be fixed by statute at sums higher than those presently awarded. It is recognized, however, that any such award is, by its nature, bound to be arbitrary and is usually offset by the awards under The Fatal Accidents Act.

The significant feature of a review of this subject is, however, that in Alberta most of the criticisms of the tort system under this heading were solved three generations ago.

\section{The Uncompensated Victim}

The introduction to this article identified four classes of automobile accident victims who do not receive reparations under the present system. The gratuitous passenger and the victim of the uninsured driver will be considered in Part V and VI (infra). These two classes can be compensated if it is desired to do so within the framework of the present tort system.

The remaining two classes of persons who at present recover nothing from an adversary under the present system are the wrongdoers, who bear all their own damage (or a part if they are only partly to blame), and those who are injured by sheer mischance in accidents for which no one is responsible. The principal mission of the advocates of no-fault systems has been to ensure compensation for these two groups of persons.

By far the largest of these classes, of course, is the wrongdoer whose negligence caused the damage. It is submitted that if the no-fault system is removed from the realm of theoretical discussion and placed in actual operation, the citizens of Alberta would find exceedingly distasteful the sight of drivers being compensated for their own negligence from the funds created by the contributions of all. The wanton driver, the speeder, the careless would receive compensation equally with the innocent.

S11 The Fatal Accidents Act. R.S.A. 1955. Ch. 111, as amended.

i) The Trustee Act, R.S.A. 1955, Ch. 346. s.s. 32-34, as repealed and amended by The Administration of Estates Act, S.A. 1969. Ch. 2, s.s. 54-56.

$\because$ Bowker, The Uniform Survival of Actions Act, (1964) 3 Alta. Law Rev. 197, and Laycraft. Survival of Claims for Loss of Expectation of Life, (1964) 3 Alta. Law Rev. 202. 
The validity of this criticism is tacitly admitted by the Wootton Commission, by the British Columbia legislation and by the Saskatchewan system when the impaired or drunken driver is excluded from the ranks of the wrongdoers who can recover. Logic would surely argue the merits of the impaired driver's case as forcefully as that of the driver whose grossly excessive speed or affinity for the wrong side of the road on a blind curve caused equal or greater havoc. To exclude one, in righteous indignation, from all assistance and to rush to the other's aid serves neither reason nor compassion. If alcoholic disability is the sole criterion, what of the drunken pedestrian?

The premise of the reformers that our judicial system cannot determine who is at fault in most automobile accidents is the only possible justification for compensating the wrongdoer equally with his innocent victim. That premise as has already been argued, does not accord with experience in Alberta. In fact, fault can be determined in virtually all cases.

Much can be said for the creation of a fund, as a social necessity, to meet the immediate financial needs of all who are injured. The systems contained in the legislation of British Columbia and Saskatchewan provide for such immediate relief although both systems provide sufficient payment to cover the majority of less serious cases. Advocates of these systems point out that in the social and commercial environment in which we live a car is no longer a luxury or even a mere convenience but is a necessity. They add that it is simple realism to meet the social costs of this new environment.

Once such payments exceed the alleviation of immediate financial hardships, however, the basic problem reasserts itself that innocence and guilt are treated as equal in merit. It is this moral conflict which is the foundation of the debate.

A review of the no-fault systems, such as that proposed by the Wootton Commission, discloses that the innocent must suffer in order that the guilty be compensated. No-fault systems are undeniably expensive, since the number of drivers to be compensated from the insurance premiums of all is vastly increased. The disparity of compensation between the actual damages now being recovered by innocent claimants and that proposed by the Wootton Commission has already been noted. The reduced recovery for the innocent must result from sharing available funds with the guilty. s:

The plight of the person injured by sheer mischance and without his own fault is a more serious problem in some respects. The driver who collides with a deer which jumped suddenly in front of him excites sympathy. While the numbers of such persons is not large, the average citizen would probably react instinctively in favour of a change in the system which would enable them to receive compensation.

It can be seriously questioned, however, whether the number of such persons is such as to warrant the convulsion to present institutions that the no-fault concept involves. It must be remembered that modern life poses threats to safety in many areas other than automobile traffic.

:3 One newspaper editorial writer in Alberta suggested as an ansu'er to criticisms of arbitrary payment scales that all injured persons recelve full damages assessed by the courts. One can sympathize with editorial writers who must reach the apogee of learning on a new subject each day. The costs of such a system. however, would come close to doubling the insurance premiums in Alberta. 
If we create an elaborate system of reparations for the victims of chance injury in one area, we provide the precedent for much wider coverage. The statistics of the National Safety League of Canada show 11,474 accidental deaths in Canada in 1967. Of these 5,412 were due to motor vehicles and 6,184 were "due to falls, drowning, fire, explosion, suffocation, poisoning, industrial machinery, blows from falling objects, fire arms, aircraft and assorted other causes." "it Of the 5,412 motor vehicle deaths, fault would have been determined in virtually all cases, leaving only a small number of persons killed in automobiles by mischance. The number killed by mischance from other causes would be much greater.

In my view, neither the numbers nor the plight of persons injured by mischance justifies the destruction of the automobile tort system. If there is demand for such coverage some provision can be made for engrafting accident coverage on to automobile coverage but the compulsory features of it should be limited to that amount which is designed to alleviate immediate financial hardship and to replace income on a short term basis.

Comprehensive no-fault coverage is essentially a field for private insurance. Any Albertan who is so minded can insure the risk of his injury or that of his family against accident from all causes including those caused by automobiles. If any public demand for such insurance exists, the industry would undoubtedly produce policies restricted to automobile risks and covering passengers, with variations from existing passenger hazard coverage in whatever ingenious form is required.

There are two possible approaches to devising the means of providing limited no-fault payments. One method would be to require that the compulsory insurance coverage be extended to income payments and death benefits for the driver and his passengers and for any pedestrian or bicyclist injured by him. The other, and probably the simplest system, would be to provide the payments from The Motor Vehicle Accidents Claims Fund, with the cost of such payments being borne by all motorists.

\section{B. Merits of the Present System}

The foregoing discussion of the criticisms of the present system will already have indicated the advantages of it. It is useful, however, to note them specifically.

1. The present system is well understood by the people of Alberta. Fault is a concept which is in accord with their training and experience and is in harmony with the remainder of the law.

2. The tort system accords with the sense of justice of the individual. We have already observed how distasteful will be the sight of the wrongdoer being compensated as a result of his own fault. The law probably owed its origin to the need of society to promote order by providing an alternative to violent remedial action by the individual. A formal court system serves as its operating instrument.

A no-fault system leaves the individual with no sense that society has come to his aid. He finds himself partially disabled for the remainder of his life, following what is probably the most dramatic episode he

if Griffiths, Don't Abolish Tort Law in Auto Accident Compensation, (1969) 12 Can. Bar Jo. 187. 
will ever experience. At that point society does not seem to condemn the wanton conduct of his adversary; rather it gives them both equal compensation. In many cases the arbitrary scale applied to the wrongdoer could give greater compensation than in his own case. The suggestion that, with all its centuries of experience, the majestic institution of the law cannot even determine which of them is at fault, he will regard as ludicrous.

3. The present tort system regards each man as an individual meriting full consideration of his individual circumstances. This point has been discussed in the preceding sections.

4. The present tort system provides a deterrent to negligence by emphasizing individual responsibility. It has become the fashion of writers on this subject to scoff at this suggestion. Moreover, there is no doubt that the greatest deterrents to careless driving are fear of injury and the sanctions imposed as punishment by the law. Yet no individual will wish to have it formally determined before all his neighbours that one of them is dead or seriously injured by his negligence. The present system does emphasize this element. It is to be contrasted with the no-fault concept, which treats wrongdoer and innocent the same and dismisses the matter without condemnation.

Yet after all the arguments are marshalled and examined, the great triumph of the common law will always be that it treats each man as an individual, and the equal of all other men before it. If this seems trite or merely theoretical, or even irrelevant to consideration of modern problems, then that system will perish. The writer submits that Albertans will not wish it so.

\section{THE GRATUITOUS PASSENGER}

- Prior to the intervention of various Canadian and American legislatures, the common law required a person, who undertook the carriage of another gratuitously, to exercise such care as is "reasonable under all the circumstances." In the decade commencing 1930, many American and Canadian jurisdictions enacted statutory provisions which either precluded recovery by the gratuitous passenger from his hostdriver altogether or limited it to cases of gross negligence. A survey by The American Bar Association in 1968 showed such statutes in 27 United States jurisdictions. In Canada the provinces of New Brunswick, Alberta, Nova Scotia, British Columbia, Ontario, Manitoba and Saskatchewan enacted a gratuitous passenger rule."ii

The first Alberta provision appeared in 1934:; and prohibited any action by the grauitous passenger against his host. In 1941 this section was changed in the new Vehicles and Highway Traffic Actix to limit recovery by the gratuitous passenger to cases of "gross negligence or wilful and wanton misconduct" by the host. This provision has remained in force and is now Section 211 of The Highway Traffic Act.:"

A. Armand v. Carr (1926) S.C.R. 575. Marsh. Negligent Injury to Gratuitous PassengerResponsibitity of Owner of Vehicle, (1930) 8 Can. Bar Rev. 68 contains a full case note on the subject.

sil Hancock. Motor Cars and Gratuitous Passengers, (1945) 23 Can. Bar Rev. 344 contains statutory citations and a review of the first ten years of this law.

at Vehicles and Highway Traffic Act 1926, Amendment Act, 1934, S.A. 1934, Ch. 62. which added Sec. $71 B$ to The Vehicles and Highway Traffic Act. S.A. 1924. Ch. 31.

$\therefore$ S.A. 1941. Ch. 5, Sec. 102.

si S.A. 1967. Ch. 30 . 
These statutes have been phrased in various terms in different jurisdictions to limit the host's liability to cases of "intentional misconduct", "wilful misconduct", "wilful and wanton misconduct", "heedless and reckless disregard" or "gross negligence."

At this point in time, it is difficult to see what induced so much legislative intervention in the common law situation. A review of legal publications during this period shows little comment either for or against the law. The American Bar Association survey states that "the inducing fact, in at least some states, seems to have been the then prevalence of hitch-hikers on the highways". It also seems the provisions "as an expression of the feeling that it is inequitable to permit a guest to profit from the ordinary negligence of his host who was in the process of conferring a benefit upon the guest."

This latter reasoning would hardly coincide with Canadian theories of damage. A guest, who has been compensated in damages for injuries suffered, can hardly have the verb "to profit" applied to him. If the system has functioned properly, the award equals the damage.

\section{Prosser on Torts, makes the following statement: ${ }^{\text {:2 }}$}

Such statutes have been the result of persistent and effective lobbying on the part of liability insurance companies. The chief argument advanced in support of them has been that in guest cases the insurer, who is required to pay the damages, is peculiarly exposed to collusion between the injured guest and a host anxious to see compensation paid, so long as he does not have to pay it-so that the truth does not come out in court, and there is a resulting increase in insurance rates. Essentially, however, the theory of the acts is that one who receives a gratuitous favor in the form of a free ride has no right to demand that his host shall exercise ordinary care not to injure him. The typical guest act case is that of the driver who offers his friend a lift to the office or invites him out to dinner, negligently drives him into a collision, and fractures his skull-after which the driver and his insurance company take refuge in the statute, step out of the picture, and leave the guest to bear his own loss. If this is good social policy, it at least appears under a novel front.

In Canada, comment in legal periodicals has roundly condemned the provisions. After observing the Ontario statute in action for ten years, a writer in 1945 commenced his article with a description of "the iniquities which flow from Sec. $47(2)$ of the Highway Traffic Act." In 1960, another writer recorded the opinion of many lawyers that "it is an unjust and uncalled for interference with common law rights." "is

Judicial comment in Canada has been limited to complaints of an inherent obscurity in the phrase "gross negligence." Most often quoted is the view of Lord Cranworth"it that there is no difference between negligence and gross negligence. It is "the same thing with the addition of a vituperative epithet."

The difficulties of interpretation occasioned by these statutes have been summarized in Posser on Torts: :"

There is perhaps no other group of statutes which have filled the courts with appeals on so many knotty little problems involving petty and otherwise entirely inconsequential points of law. There is first of all the question of who is a "guest". What is the effect of sharing expenses, or of the guest buying a tank of gasoline? Of an indirect prospective, or merely remotely potential, benefit to

no Prosser on Torts, 3d. cd., at 190.

(i) American Bar Association Report, supra, n. 41 at 86-87.

i: Prosser on Torts, supra, n. 60 at 191.

tii Hancock, supra, n. 48.

ii MacArthur. Gross Negligence and the Guest Passenger, (1969) 38 Can. Bar Rev. 47

(i.) Armand v. Cart (1926) S.C.R. 575; Holland v. Toronto (1927) S.C.R. 242.

iv Wilson v. Brett (1843) 152 E.R. 737 at 739.

ii Prosser on Torts, supra, $n$. 60 at 191. 
the host in the form of some business interest or hope in having the guest take the ride? Of an employer's order prohibiting the driver from taking free riders; of the fact that the guest is not invited, but allowed to stay after he trespasses; of the fact that the plaintiff is a child too young to know that he is a guest? of the fact that the guest was out of the car for a moment when he was run down; of his demand to be let out of the car; of his assent even to the aggravated misconduct? Can the owner of the car be a guest in it when someone else is driving? And finally, what is the meaning, and application, of "gross", "wilful", "wanton", "reckless", or whatever other terms the statute may adopt.

It is submitted that the gratuitous passenger provision of The Highway Traffic Act, Section 211 should be repealed. There can be no doubt that many honest and innocent victims of provable negligence are being deprived of compensation in order that a few who may collude may not be tempted. Justice denied to many on the ground that the few may be tempted to perjure themselves, must be opposed to all principle.

Moreover, it is submitted that confidence can be placed in the judicial system to winnow out virtually all such attempts at collusion between driver and guest and to deter repetition by punishment. Our courts merit that confidence. It is also true that the investigation of accidents is much more sophisticated today than in 1934. Police and insurance investigation is expert and commenced promptly, so that the colluding driver and his guest must arrive at the detail of their fraudulent story at a very early stage, while still in shock, and maintain it against all investigation. Again, it is submitted that the small incidence of successful fraud does not justify the social evil involved in this interference with the common law.

\section{COMPULSORY INSURANCE}

The problem of the uninsured or inadequately insured motorist continues in Alberta despite the efforts of the "green certificate" system to induce drivers to obtain insurance and despite the sales efforts of the industry to persuade customers to buy higher limits. The report of the Special Legislative Committee in Alberta notes': that there were 18,000 vehicles on Alberta roads carrying green certificates and therefore uninsured.

The plain fact is that responsible citizens now bear the cost of insuring the risks of their own operation of motor vehicles and also as a group bear the costs which should be borne by the uninsured. When a loss caused by the uninsured is borne by an individual, the result can be catastrophic even though The Motor Vehicle Accident Fund pays up to minimum limits.

Compulsory insurance is, of course, the most direct route to a solution of this problem. It also appears to have considerable public support, but is opposed by the Insurance Industry.

The American Bar survey quotes a public opinion poll conducted in 1961 by the Opinion Research Corporation of Princeton showing affirmative answers by 92 per cent of those who were asked the question: "Do you think all car owners should be required by law to carry automobile liability insurance or not?"

The report of The American Bar Special Committee supported compulsory insurance in these terms: ii

os Report of Special Legislative Committee, supra, $\mathbf{n} .17$ at 8.

60 Report of the American Bar Assoclation, supra, $n$. 41 at 124. 
We deem it imperative that the financial responsibility gap be closed, and we believe that the benefits from doing so far outweigh any disadvantage that we can perceive. We realize that the problem of finding ways of administering compulsory insurance laws with due regard to a proper balance between the cost and other burdens of rigorous administration, and the desire for maximum effectiveness, is one that deserves careful study.

Our recommendation is that the states that have not done so adopt compulsory automobile insurance laws applicable to both bodily injury and property damage liability ... We view [this] as an important and much needed improvement.

One objection to compulsory insurance noted by the Committee was the fear of the insurance industry that compulsory insurance leads to regulation of rates and to increased claims frequency. The Committee observed," however, that "rate regulations in some form is in effect everywhere", and that increased claims frequency is precisely the result which is sought-that of making uninsured motorists worth suing by making them financially responsible. The Committee stated: ${ }^{71}$

A high claims frequency is evidence that such laws are doing what they are intended to do-protect the innocent traveller upon the highway from sustaining uncollectible damages because of the negligence of financially irresponsible drivers .... An increase in claims frequency is not the fault but the natural and desirable outcome of compulsory insurance.

The Wootton Commission heard much evidence on this subject, including an oposing brief from the All Canada Insurance Federation, and published its findings.:

The Commission divided the objections into three groups, ideological, economic, and administrative, and stated them as follows:

1. Rates become a political football. The Committee believed that it is not possible to avoid insurance rates becoming an issue of Public Policy in any event, and that the existence of an Insurance Commissioner in each province confirms that fact.

2. Compulsion is undesirable in a free society. The Commission agreed that this is so, but observed that compulsions and restrictions of necessity abound in a complex society because the collective good demands it. The question to be decided is whether this collective good outweighs the undesirablity of another area of compulsion.

3. Monopolistic state insurance is the inevitable next step. The Commission denied this premise, and stated its view that a private, competitive insurance industry is the best insurance system. It did not believe that compulsory insurance means state insurance.

4. Compulsory insurance is difficult to enforce. The All-Canada Insurance brief stated that enforcing compulsory insurance in New York State in 1963 cost $\$ 3.5$ million. The Commission observed, however, that this covered 5.5 million cars and amounted to 65 cents per vehicle. Moreover, enforcement problems in the complex urban society of New York could be expected to exceed those in Western Canada. Compulsory insurance has now been successfully administered in New York State for more than ten years.

5. Compulsory insurance increases costs due to higher claims frequency which is itself traceable to greater claims consciousness and an increase in illegitimate claims. The Commission reviewed this argument by a comparison of detailed claims statistics over a ten year period

70 Id., at 123.

i1 Id at 123 .

i2 Wootton Report, Volume II at 566-581. 
from California where there is no compulsion in insurance and from New York where compulsion was introduced in 1957. During that period, average paid claim frequencies improved more in New York than in California. Thus there does not appear to be statistical proof of this point in the one example tested.

6. The average insured would buy less insurance and would tend to limit his purchase to the minimum required by law. It is difficult to see the reason why this would be so. The citizen who regards high limits as necessary protection to his financial future will continue to do so. He will continue to receive such advice from his responsible insurance agent.

7. Industry witnesses before the Commission doubted that compulsory insurance would effect much increase in the percentage of insured motorists. Again, with adequate enforcement, this point seems doubtful. Eighteen thousand Albertans have paid an extra $\$ 20.00$ in lieu of insurance. Surely most of these persons would buy insurance, if the alternative is not to drive at all. If insurance is a requirement for a license, enforcement should reduce the number of uninsured motorists to the number prepared to drive in breach of the law.

8. Compulsory insurance removes underwriting judgment and puts on the road, drivers who should not be there. The Commission concluded, however, that the elimination of bad drivers from the road should not be the function of the insurance company. Moreover, since insurers have long found it necessary to establish assigned-risk plans and pools to provide insurance for the driver whose application has been refused, it seems clear that insurers do not regard it as their function to rule bad drivers off the road.

On the whole, it is submitted that the case against compulsory insurance is not convincing. It is recognized that it provides another area of compulsion in a society which is perhaps replete with them. The social evil, which the uninsured driver presents, is, however, so evident as to justify entry of the state into this area.

One alternative often suggested is to require uninsured motorist hazard coverage in the standard automobile policy. Such coverage promises to pay the damages the policyholders sustain in person by reason of the negligence of the owner or operator of the uninsured motor vehicle. In 1968 eleven states made this coverage mandatory in an automobile liability policy.:"it

Where the percentage of insured motorists is relatively low, the cost of this coverage would be substantial. In jurisdictions such as New York, which has a compulsory insurance law in any event, such a provision would not be expensive and would represent merely a plugging of whatever small loophole is left open after strict enforcement of the compulsory insurance law.

Uninsured Motorist Hazard coverage has two difficulties inherent in it, however. In principle, it hardly seems proper to require the responsible insured motorist to pay, by his premiums, the cost of the uninsured risks of those who refuse to insure. Secondly, when a claim is made under this coverage, a conflict of interest arises between the policy-

i3 Connecticut. Illinois, Maine, Massachusetts, New Hampshire, New York, Oregon, South Carolina. Vermont. Virginia, West Virginia. 
holder and the insurer. The best interest of the insurer is to defend the uninsured motorist against its own policyholder; he in turn seeks to collect damage from the uninsured at the expense of his own company. In a relationship, which must be characterized by utmost good faith, this is a most undesirable conflict.

Compulsory motor vehicle liability insurance is a necessity under modern traffic conditions. The "green card" system has not proven capable of removing the uninsured driver from the road, and that species of irresponsibility continues to be a major defect in our reparations system.

Moreover, the same principles apply, with a mere difference in degree, to the inadequately insured motorist. Where substantial loss is only partly compensated, the system has failed just as surely as though no part of the loss is covered.

The recent report of the Alberta Legislative Committee recommended compulsory insurance administered by the insurance industry, but advocated the retention of the wholly inadequate limit of $\$ 35,000.00$. The Committee observed that very few claims exceed that sum. This latter consideration is in fact irrelevant. If there are many claims above $\$ 35,000.00$, the social need for coverage is greater than if there are only a few but the principle is the same. The fact that such claims are rare merely means that increasing the limits of insurance to adequate coverage can be done for the cost of a tank of two of gasoline. Whatever be the cost, it must be borne.

In fact, additional adequate coverage does not involve prohibitive cost. In August, 1969 a public liability rate schedule, quotes for a typical motorist in Calgary with a three year accident free record, was as follows:

$\$ 35,000.00$ (minimum limit)
$50,000.00$
$100,000.00$
$200,000.00$
$300,000.00$

66.00

An objection to universally high limits has been that juries tend to award higher damages than are proper, secure in the knowledge that the award is within the probable limits of insurance. It is submitted that in a system that rarely uses juries, this is not a factor which outweighs the need for adequate coverage.

It is, however, difficult to fix any minimum limit to insurance coverage without immediately meeting the same difficulty involved in inadequate limits, varying only in degree. Whatever limit is fixed, the exceptional case will be found to exceed it. Consideration should be given to the underwriting problems involved in no-limit insurance such as that in force in England.

\section{CONCLUSION}

He who defends any legal institution in this era of rapid social change exposes himself to those who scoff at all traditional values. If he is a lawyer he attracts the additional charge of self-interest. That is not to say that the test this process involves is not of great value, both to the institution and to its defenders. 
The law has exhibited a most remarkable adaptability and vitality in the face of criticism, and has profited from it. As the social environment changes, the tort system, which Prosser called "the battleground of social theory", will change to achieve the results society requires from it. Albertans would be wrong, however, to confuse the need for change with a need to destroy that system. 